\title{
Microwave Assisted Oxidation of $N, N$-Dimethylaniline by Ditertiarybutyl Chromate in Non-Aqueous Media
}

\author{
RICHA KUMARI ${ }^{1}$, SNIGDHA LAL ${ }^{1}$, ANITA KUMARI GUPTA ${ }^{2}$, \\ SANGITA KATRE $^{3}$ and HARI OM PANDEY ${ }^{4}$
}

${ }^{1}$ Departement of Chemistry, Ranchi University, Ranchi- 834008, Jharkhand, India

${ }^{2}$ Department of Chemistry, S S Memorial College, Ranchi University, Ranchi-834008, India

${ }^{3}$ Department of Chemistry, C J Patel Arts, Commerce, Science \& Post-graduate College, Tirora, R T M Nagpur University, Maharashtra-441911, India

${ }^{4}$ Department of Chemistry, Ranchi University, Ranchi- 834008, Jharkhand, India

rahangdalebs@yahoo.co.in

Received 2 November 2013 / Revised 25 November 2013/ Accepted 2 January 2014

\begin{abstract}
Microwave assisted organic synthesis has grown into a powerful tool in the hands of chemists. In the present paper we report the study of products of oxidation of $N, N$-dimethylaniline by ditertiary butyl chromate in few non aqueous solvents like acetonitrile, tetrahydrofuran and dioxane. The substrate solution and ditertiary butyl chromate was taken in appropriate ratio, mixed, stirred and irradiated in domestic microwave for the specified periods. The solid products of different colour and compositions so obtained were studied by elemental analysis, FTIR curves and thermogravimetric mass loss pattern.
\end{abstract}

Keywords: $N, N$-Dimethylaniline, Ditertiarybutylchromate, Dioxane, Tetrahydrofuran

\section{Introduction}

Microwave as a source of energy was first invented by Percey Spencer in $1947^{1}$. Gedye et al., has the credit to introduce microwave in organic syntheses in $1986^{2}$. Microwave assisted organic synthesis (MAOS) and microwave induced organic reaction enhancement (MORE) have developed into powerful tool for organic syntheses since then. In comparison to conventional energy source like heating etc., microwave irradiation leads to greater efficiency, better yield, enhanced specificity and less pollution with less energy consumption. Lidstrom et al., ${ }^{3}$ published a detailed review of the organic reactions carried out by the application of microwave.

$N, N$-Dimethylaniline is a yellowish brown toxic liquid insoluble in water. It is precursor to many commercially important dyes such as malachite green and crystal violet. The oxidation of $N, N$-dimethylaniline by cupric chloride or by chloranil gives $N$-p-dimethyl 
aminobenzyl- $N$-methylaniline, 4,4'-bisdimethylaminodiphenyl methane, crystal violet and methyl violet ${ }^{4}$. The anodic oxidation of $N, N$-dimethylaniline at Pt electrode in acidic buffer leads to $N, N, N^{\prime}, N^{\prime}$-tetramethylbenzidine ${ }^{5}$. In addition to the electro-oxidative coupling as

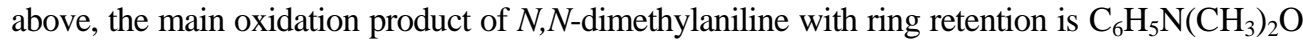
whereas oxidation with ring degradation may lead to variety of products.

Keeping in view, the increasing use of microwave irradiation as a source of clean energy $^{6}$, in conformity with the 12 principles of green chemistry ${ }^{7}$, the authors have undertaken the oxidation of $N, N$-dimethylaniline with ditertiary butyl chromate in microwave in non-aqueous solvents. The choice of ditertiary butyl chromate ${ }^{8}$ out of many chromium(VI) based oxidants like Collin's reagent ${ }^{9}$, pyridinium chlorochromate ${ }^{10}$, pyridinium florochromate ${ }^{11}$, tetramethyl ammonium florochromate ${ }^{12}$, quinolinium chlorochromate ${ }^{13}$ etc. is based on its docility accompanied with versatility towards organic substrates. Moreover, the preparation of ditertiary butyl chromate is less cumbersome in comparison to the preparation of other variants of chromium (VI). The oxidation products may serve as ligands to form adducts or complexes of chromium in different oxidation states $^{14,15}$. The study of these products may lead to valuable generalizations with regards to the mechanism and other aspects of the reaction.

\section{Experimental}

The chemicals used were all A.R. grade. Only freshly prepared solutions were used. The oxidant was prepared by dissolving crystals of $\mathrm{CrO}_{3}$ in minimum quantity of tert. Butyl alcohol followed by filtration and decantation to get clear brown solution. Sample-601 was prepared by mixing a solution of $1 \mathrm{~g}(0.01 \mathrm{~mol})$ of chromium trioxide in $10 \mathrm{~mL}$ of tert. butyl alcohol and a solution of $1.2 \mathrm{~mL}(0.01 \mathrm{~mol})$ of $N, N$-dimethylaniline in $10 \mathrm{~mL}$ of acetonitrile as per the requirement for 1:1 oxidant:substrate ratio. The other samples R-602, R-603 were prepared by mixing solution of $0.01 \mathrm{~mol}$ of chromium trioxide in tert .butyl alcohol and solution of 0.02 and 0.03 mols of substrate required for $1: 2$ and $1: 3$ oxidant:substrate ratio in acetonitrile as solvent for the substrate. Similarly, samples R-604, R-605 and R-605 were prepared by the same procedure using tetrahydrofuran as solvent for substrate and samples R-606 and R-608 in solvent dioxane for the same. In all the cases, the solutions were mixed stirred and then irradiated in LG household microwave oven, MG-3937 C (microwave frequency $2450 \mathrm{MHz}$ ) for the period specified in Table 1 . The solid products obtained, were washed several times until clear washing before collecting them as solid samples with symbols as above. The estimation of chromium in the products was done volumetrically using $\mathrm{K}_{2} \mathrm{~S}_{2} \mathrm{O}_{8}$ (in excess), $0.1 \mathrm{~N} \mathrm{~K}_{2} \mathrm{Cr}_{2} \mathrm{O}_{7}$ solution and $0.1 \mathrm{~N}$ Mohr's salt solution. Elemental analysis of carbon, hydrogen and nitrogen was carried out by Elemental Analyser (Heraeus Vario EL III Carlo Erba 1108). FTIR spectra of the products were recorded on FTIR Spectrophotometer (Shimadzu 8201 PC). TGA was done on Thermal Analysis System (Perkin Elmer Diamond TG/DTA).

\section{Results and Discussion}

On the basis of observations as in Table 1 and Table 2, following generalization could be made:

- The reaction is much efficient in acetonitrile as a solvent than either in THF or dioxane. In acetonitrile it takes only $10 \mathrm{sec}$. as compared to 20 sec. in other cases.

- The products R-607 and R-608, as obtained in case of dioxane as solvent for substrate are almost same except that the number of water molecules is slightly less in case of higher oxidant : substrate ratio. 
- The oxidation product in all the cases from R-601 to R-608 is $N, N$-dimethylaniline- $N$ oxide which gets associated with reduced chromium to form solid products.

- In samples R-601, R-602 and R-603 which are obtained in case of acetonitrile as solvent, chromium has gone to oxidation state as low as II whereas in other cases it is mostly in most stable III state.

- As we go from sample R-601 to R-603, the number of water molecules increases i.e. less number of water molecules get associated in the products when the ratio of oxidant is more. This is observed in case of THF and dioxane as solvent as well.

- The colour of the products in almost all the cases is grey which may be due to charge transfer in the mixed oxide of chromium.

- As per formulations arrived at, the reaction did not results in any coupling of the rings as reported earlier ${ }^{3,4}$.

- Recrystallization of the products in suitable solvent and the study of the crystals formed may be the further course of investigation.

Table 1. Reactants

\begin{tabular}{|c|c|c|c|c|c|}
\hline $\begin{array}{l}\text { Product } \\
\text { Code }\end{array}$ & Substrate & Solvent & Oxidant & $\begin{array}{c}\text { Oxidant:Substrate } \\
\text { Ratio }\end{array}$ & $\begin{array}{l}\text { Irradiation } \\
\text { Time }\end{array}$ \\
\hline $\mathrm{R}-601$ & DMA & Acetonitrile & TBC & $1: 1$ & $10 \mathrm{sec}$ \\
\hline R-602 & , , & , & ,' & $1: 2$ & $10 "$ \\
\hline $\mathrm{R}-603$ & , & , & , & $1: 3$ & $10^{\prime \prime}$ \\
\hline R-604 & , & THF & , & $2: 1$ & $20 "$, \\
\hline R-605 & , & , & , & $1: 1$ & 20 \\
\hline R-606 & , & , & , & $1: 2$ & 20 \\
\hline R-607 & , & Dioxane & , & $2: 1$ & 20 \\
\hline $\mathrm{R}-608$ & , & , &, & $1: 1$ & 20 \\
\hline
\end{tabular}

Table 2. Products

\begin{tabular}{|c|c|c|c|c|}
\hline $\begin{array}{l}\text { Product } \\
\text { Code }\end{array}$ & Colour & $\begin{array}{l}\text { Solubility } \\
\text { in Water }\end{array}$ & $\begin{array}{l}\text { Empirical } \\
\text { Formula }\end{array}$ & Formulation \\
\hline $\mathrm{R}-601$ & Ash Grey & Insoluble & $\mathrm{Cr}_{5} \mathrm{C}_{9} \mathrm{H}_{27} \mathrm{O}_{14} \mathrm{~N}$ & $\begin{array}{l}2 \mathrm{Cr}_{2} \mathrm{O}_{3} \text {. CrO.HCOOH. } \\
\mathrm{C}_{6} \mathrm{H}_{5} \mathrm{~N}\left(\mathrm{CH}_{3}\right)_{2} \mathrm{O} .4 \mathrm{H}_{2} \mathrm{O}\end{array}$ \\
\hline R-602 & Dark Grey & ," & $\mathrm{Cr}_{5} \mathrm{C}_{8} \mathrm{H}_{31} \mathrm{O}_{17} \mathrm{~N}$ & $2 \mathrm{Cr}_{2} \mathrm{O}_{3} \mathrm{CrO} . \mathrm{C}_{6} \mathrm{H}_{5} \mathrm{~N}\left(\mathrm{CH}_{3}\right)_{2} \mathrm{O} .9 \mathrm{H}_{2} \mathrm{O}$. \\
\hline $\mathrm{R}-603$ & Dark Grey & , & $\mathrm{Cr}_{7} \mathrm{C}_{10} \mathrm{H}_{46} \mathrm{O}_{26} \mathrm{~N}$ & $\begin{array}{l}3 \mathrm{Cr}_{2} \mathrm{O}_{3} \mathrm{CrO} \cdot \mathrm{C}_{6} \mathrm{H}_{5} \mathrm{~N}\left(\mathrm{CH}_{3}\right)_{2} \mathrm{O} \\
2 \mathrm{HCOOH} \cdot 11 \mathrm{H}_{2} \mathrm{O}\end{array}$ \\
\hline R-604 & Dark Grey & ," & $\mathrm{Cr}_{6} \mathrm{C}_{13} \mathrm{H}_{39} \mathrm{O}_{22} \mathrm{~N}$ & $\begin{array}{l}3 \mathrm{Cr}_{2} \mathrm{O}_{3} \cdot \mathrm{C}_{6} \mathrm{H}_{5} \mathrm{~N}\left(\mathrm{CH}_{3}\right)_{2} \mathrm{O} \\
5 \mathrm{HCOOH} \cdot 2 \mathrm{H}_{2} \mathrm{O}\end{array}$ \\
\hline R-605 & Ash Grey & , & $\mathrm{Cr}_{4} \mathrm{C}_{8} \mathrm{H}_{23} \mathrm{O}_{16} \mathrm{~N}$ & $2 \mathrm{Cr}_{2} \mathrm{O}_{3} . \mathrm{C}_{6} \mathrm{H}_{5} \mathrm{~N}\left(\mathrm{CH}_{3}\right)_{2} \mathrm{O} .9 \mathrm{H}_{2} \mathrm{O}$ \\
\hline R-606 & Dark Grey & $\begin{array}{l}\text { Sparingly } \\
\text { Soluble }\end{array}$ & $\mathrm{Cr}_{3} \mathrm{C}_{9} \mathrm{H}_{23} \mathrm{O}_{16} \mathrm{~N}$ & $\begin{array}{l}\mathrm{Cr}_{2} \mathrm{O}_{3} \mathrm{CrO} . \mathrm{C}_{6} \mathrm{H}_{5} \mathrm{~N}\left(\mathrm{CH}_{3}\right)_{2} \mathrm{O} \\
\mathrm{HCOOH} .9 \mathrm{H}_{2} \mathrm{O}\end{array}$ \\
\hline $\mathrm{R}-607$ & Ash Grey & ," & $\mathrm{Cr}_{4} \mathrm{C}_{9} \mathrm{H}_{27} \mathrm{O}_{13} \mathrm{~N}$ & $\begin{array}{l}2 \mathrm{Cr}_{2} \mathrm{O}_{3} \cdot \mathrm{C}_{6} \mathrm{H}_{5} \mathrm{~N}\left(\mathrm{CH}_{3}\right)_{2} \mathrm{O} \\
\mathrm{HCOOH} .4 \mathrm{H}_{2} \mathrm{O}\end{array}$ \\
\hline $\mathrm{R}-608$ & Ash Grey & Insoluble & $\mathrm{Cr}_{4} \mathrm{C}_{8} \mathrm{H}_{26} \mathrm{O}_{14} \mathrm{~N}$ & $2 \mathrm{Cr}_{2} \mathrm{O}_{3} \cdot \mathrm{C}_{6} \mathrm{H}_{5} \mathrm{~N}\left(\mathrm{CH}_{3}\right)_{2} \mathrm{O}$. HCOOH. $5 \mathrm{H}_{2} \mathrm{O}$. \\
\hline
\end{tabular}

\section{Acknowledgement}

The authors are thankful to CIF, BIT, Mesra, Ranchi for elemental analysis, FTIR curves and Research \& Development centre, Tejpur University, Assam for DTA-TGA analysis of the samples. 


\section{References}

1. Spencer, Percy L, Methods of treating foodstuff. US. Patents- 2495429, Jan-24, 1950.

2. Gedye R, Smith F, Westaway K, Ali H, Balidsera L, Lorraine B and Rousell J, Tetrahedron Lett., 1986, 27(3), 279-282; DOI:10.1016/S0040-4039(00)83996-9

3. Lidstrom P, Tierney J, Wathey B and Westman J, Tetrahedron Report No. 2001, 589(57), 9225-9283.

4. $\quad$ Lindsay J R Norman R O C and Walker W M, J Chem Soc B: Phys Org., 1968, 0, 66-71.

5. Mizoguchi T and Adams R N, J Am Chem Soc., 1961, 84(11), 2058-2061; DOI:10.1021/ja00870a009

6. Loupy A, Petit A, Hamelin J, Françoise T B, Jacquault P and Mathe D, Synthesis, 1998, 09, 1213-1234; DOI:10.1055/s-1998-6083

7. “The 12 principles of Green Chemistry" United States Environmental Protection Agency, Retrieved-31, 2006.

8. Oppenauer R V and Oberrauch H, (Univ. Innsbruck, Austria), Anaus Assoc Guin Argentina, 1949, 37, 246-262.

9. $\quad$ Collins J C, Hess W W and Frank F J, Tetrahedron Lett., 1968, 9(30), 3363-3366; DOI:10.1016/S0040-4039(00)89494-0

10. Corey E J and Suggs J W, Tetrahedron Lett., 1975, 16(31), 2647-3650; DOI:10.1016/S0040-4039(00)75204-X

11. Bhattacharjee M N, Choudhuri M K, Dasgupta H S, Roy N and Khathing D T, Synthesis, 1982, I(7), 588-590; DOI:10.1055/s-1982-29872

12. Kassaee M Z, Mahjoub A R and Ghammani S, Tetrahedron Lett., 2003, 44(24), 45554557; DOI:10.1016/S0040-4039(03)00989-4

13. Srinivasan R, Ramesh C V, Madhulatha W and Balasubramaniam K, Indian J Chem., 1996, 35B, 480-484.

14. Katre S, Gupta A K and Pandey H O, Asian J Expt Sci., 2012, 26(1), 1-4.

15. Gupta A K and Pandey H O, Asian J Expt Sci., 2012, 26(2), 43-46. 